\title{
Appreciation
}

\section{Professor C.H. Fernando (1929-2018)}

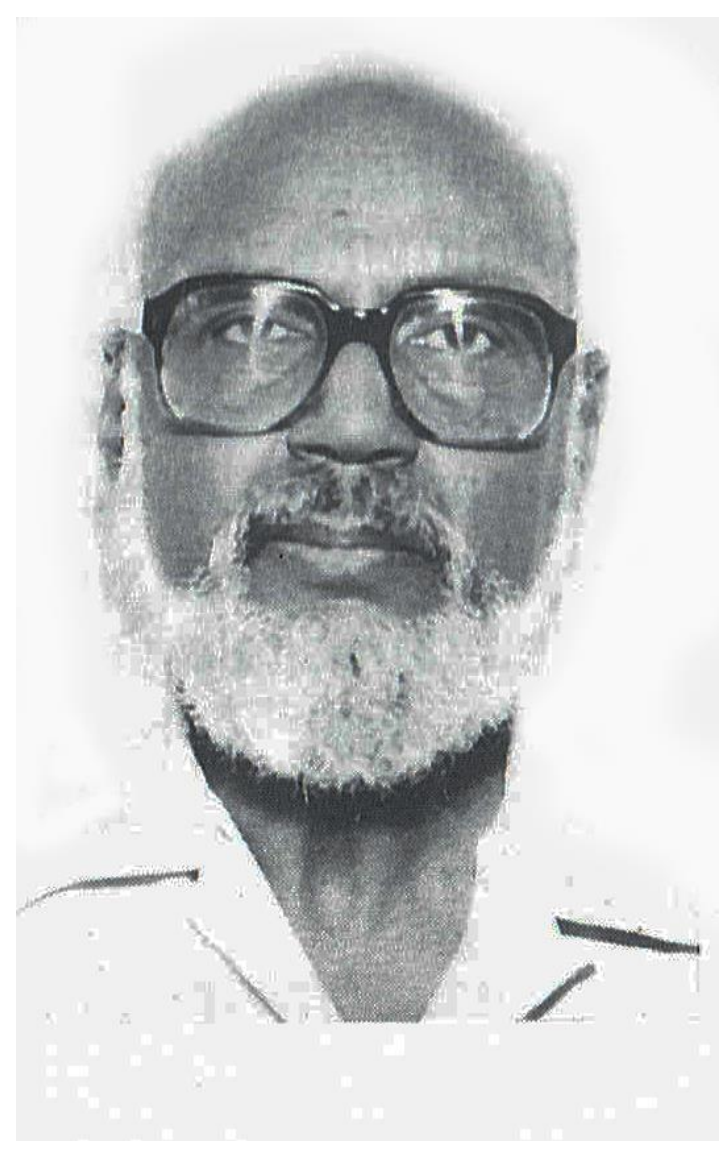

In early 1980s, a tall middle-aged and smiling gentleman walked into the Office of the Inland Fish Breeding Station at Polonnaruwa, where I was working as the Officer in Charge, introduced himself as C H Fernando and said that he was working at the same place as a research officer for nearly a year in 1960s, and wished to see the developments that have taken place at the Station since then. I already knew him by name, but not in person. There were a few workers who had worked with him. His visit was towards the end of the year. We were busy making preliminary preparations for breeding and seed production of different varieties of cultivable exotic carps, during their incoming breeding season, that would coincide with the period of the North-East monsoons. I welcomed him and took him on a round to see the brood-stocks, breeding and nursery facilities, rearing ponds, etc. While walking, he asked me as to why fish breed only during the rainy season of the year. I did not have a ready answer for that question, although I knew that the breeding season of fish coincides with the rainy season. He said that as carps were riverine species, their gonadal 
development and breeding would coincide with rainy season, and he emphasized that carps would not be suitable for reservoirs where riverine conditions would not prevail.

He was living in Canada and working as a Professor of Biology at the University of Waterloo. The friendship between us started on that day continued for a long period. We were communicating with each other by letter, and later by email. Every time $\mathrm{CH}$ visited Sri Lanka he visited me, or invited me to the place where he was residing in Colombo. Our talks were almost exclusively on inland fisheries. We have published two articles together in journals. He was of the view that tilapia is the most suitable fish for development inland fisheries as it breeds naturally in reservoirs (unlike exotic carps which need to be induced for breeding under local conditions by injecting hormones), survives under difficult conditions, grows faster, and acceptable globally as a food fish. According to $\mathrm{CH}$, concentrating on breeding of exotic carps and stocking in reservoirs would be a waste of money and time as the growth and survival of exotic carps is poor, and exotic carps are not much acceptable to fish consumers. In fact, $\mathrm{CH}$ was exponent in his view that tilapias (Oreochromis mossambicus and $O$. niloticus) being species pre-adapted to live in lacustrine habitats, would be able to colonize successfully lacustrine condition in reservoirs of Sri Lanka and elsewhere, because in many tropical geographical regions, due to absence of natural lakes, there were no lacustrine and/or lacustrine adapted species in indigenous fish fauna, which can colonize lacustrine habitats in reservoirs. Based on this opinion, $\mathrm{CH}$ had been opposing stocking of carps in reservoirs, on the argument that those temperate riverine species cannot colonize lacustrine habitats in reservoirs, which would require regular stocking. Regarding this opinion, he was having friendly arguments with Upali Amarasinghe, who accompanied him during most of his visits to Sri Lanka. In the scientific meetings, where he has presented his view about fish introduction into freshwaters, we enjoyed his presentations and especially his friendly interactions with the audience. Apart from scientific gatherings, there were several social gatherings where many of our colleagues have participated. According to Upali Amarasinghe, who had a social gathering with Dr. V.V. Sugunan, a reservoir fisheries scientist from India, in the residence of one of his relatives in Dunagaha, Sri Lanka, $\mathrm{CH}$ has prepared tasty meals. Upali also mentioned that when CH visited Ceske Budejovice in Czech Republic to attend a conference in 1997, he has prepared tasty Sri Lankan dishes and invited several conference participants for dinner.

Born in 1929, CH obtained an honours degree in Zoology in early 1950s from the then University of Ceylon (currently the University of Colombo). In 1953 on a government scholarship he proceeded to the University of Oxford, and studied for a D.Phil. at the Christ Church College. His area of research was aquatic insects. After completing D.Phil., CH returned to Sri Lanka and started his career in research and teaching at the University Colombo. In 1959 he moved to Singapore and started working at the University of Singapore. He returned to Sri Lanka in 1964, and started working in the Department of Fisheries as a research officer. It was during this time that $\mathrm{CH}$ had worked at the Polonnaruwa Fish Breeding Station for a few months. In 1965, he left for Canada and joined the University of Waterloo as an Associate Professor in Biology. Subsequently $\mathrm{CH}$ rose to the position of a full professor at the University of Waterloo.

$\mathrm{CH}$ has contributed to science by publishing more than 250 research papers and editing six books on aquatic biology. He retired in 1998, and the University of Waterloo appointed him as a Professor Emeritus in consideration of his contribution to science. The Sri Lanka Association for Fisheries and Aquatic

Resources appointed $\mathrm{CH}$ as an honorary member of the Association. After a brief illness he passed away in Waterloo on 18 September 2018. So, left a great man of science.

\section{A. Hettiarachchi}

Former Director General (Technical)

Ministry of Fisheries and Aquatic Resources Development, Sri Lanka 